\title{
Optimization and validation of a reversed-phase high performance liquid chromatography method for the measurement of bovine liver methylmalonyl-coenzyme a mutase activity
}

Bazoumana Ouattara*, Mélissa Duplessis and Christiane L Girard

\begin{abstract}
Background: Methylmalonyl-CoA mutase (MCM) is an adenosylcobalamin-dependent enzyme that catalyses the interconversion of (2R)-methylmalonyl-CoA to succinyl-CoA. In humans, a deficit in activity of MCM, due to an impairment of intracellular formation of adenosylcobalamin and methylcobalamin results in a wide spectrum of clinical manifestations ranging from moderate to fatal. Consequently, MCM is the subject of abundant literature. However, there is a lack of consensus on the reliable method to monitor its activity. This metabolic pathway is highly solicited in ruminants because it is essential for the utilization of propionate formed during ruminal fermentation. In lactating dairy cows, propionate is the major substrate for glucose formation. In present study, a reversed-phase high performance liquid chromatography (RP-HPLC) was optimized and validated to evaluate MCM activity in bovine liver. The major aim of the study was to describe the conditions to optimize reproducibility of the method and to determine stability of the enzyme and its product during storage and processing of samples.
\end{abstract}

Results: Specificity of the method was good, as there was no interfering peak from liver extract at the retention times corresponding to methylmalonyl-CoA or succinyl-CoA. Repeatability of the method was improved as compared to previous RP-HPLC published data. Using $66 \mu \mathrm{g}$ of protein, intra-assay coefficient of variation (CV) of specific activities, ranged from 0.90 to $8.05 \%$ and the CV inter-day was $7.40 \%$. Storage and processing conditions (frozen homogenate of fresh tissue vs. fresh homogenate of tissue snapped in liquid nitrogen) did not alter the enzyme activity. The analyte was also stable in liver crude extract for three frozen/thawed cycles when stored at $-20^{\circ} \mathrm{C}$ and thawed to room temperature.

Conclusions: The improved method provides a way for studying the effects of stages of lactation, diet composition, and physiology in cattle on MCM activity over long periods of time, such as a complete lactation period. Interestingly, this sensitive and accurate method could benefit the study of the cobalamin status in experimental studies and clinical cases.

Keywords: Methylmalonyl-CoA mutase, Liver, Cattle, Dairy cow, Succinyl-CoA, RP-HPLC

\section{Background}

Methylmalonyl-CoA mutase (MCM) is a bacterial and vertebrate adenosylcobalamin-dependent enzyme that catalyses the interconversion of (2R)-methylmalonyl-CoA to succinyl-CoA [1]. In some bacteria, such as Propionibacterium shermanii, MCM is important for the fermentation of pyruvate to propionate [2]; linking the production of propionate from succinate in a reverse metabolic pathway [3]. In

\footnotetext{
* Correspondence: bouattus@gmail.com

Dairy and Swine Research and Development Centre, Agriculture and AgriFood Canada, 2000 College Street, Sherbrooke, Quebec J1M 0C8, Canada
}

higher animals, including human, MCM is required for the metabolism of methylmalonyl-CoA [4]. In humans, a deficit in activity of MCM, due to an impairment of intracellular formation of adenosylcobalamin and methylcobalamin, respective cofactors for the $\mathrm{MCM}$ and methionine synthase, results in a wide spectrum of clinical manifestations (reviewed by Carrillo-Carrasco [5]). Methylmalonyl-CoA is produced by catabolism of odd-chain fatty acids and some amino acids such as valine, isoleucine and methionine. This metabolic pathway has a high flux level in ruminants for gluconeogenesis from large amounts of propionate 
formed during ruminal fermentation [6]. Therefore, in ruminants, MCM plays a major role in energy production via succinyl-CoA, an essential step for its entry in Krebs cycle [7]. In dairy cows, increasing affinity of MCM for its cofactor increases gluconeogenesis [8]. Owing to its importance, determining the activity of MCM is the subject of abundant literature [8-28]. Several methods based on the quantification of succinyl-CoA produced from methylmalonyl-CoA, have been used to study MCM activity. The radioassay based on the permanganate oxidation of DL[CH3- $\left.{ }^{14} \mathrm{C}\right]$ methylmalonyl-coenzyme $\mathrm{A}$ is the most commonly used. Unfortunately, sensitivity and reproducibility of the radiometric method are low [7,29]. To overcome these problems, a spectrophotometric assay has been developed to allow a more accurate estimation of MCM kinetic parameters $[7,8]$ however, spectrophotometric methods are more appropriate for studying the activity of purified enzyme. An electrophoretic separation method for MCM activity using surfactant for separation was also proposed [30]. However, the injection of high-con centration surfactant into the electrophoretic capillary may decrease both the separation efficiency and the reproducibility [31]. Other chromatographic techniques were also used to measure MCM activity [19,29]. However the existing liquid chromatographic methods suffer from a lack of validation data to support their routine use. In the present work, a RP-HPLC method was optimized and validated to measure MCM activity in bovine liver. The analyte stability in regard to tissue storage conditions was assessed. The performance of the method was evaluated by measuring holo and total MCM activity in the liver of six cows. Coefficients of variation (CV) and standard deviation of repeated analyses, as well as system suitability parameters were determined. The major aim of the study was to describe the conditions to optimize reproducibility of the method.

\section{Methods}

\section{Reagents and chemicals}

Methylmalonyl-coenzyme A (lithium salt), succinyl-coen zyme A (sodium salt), 5' -deoxyadenosylcobalamin (Ado $\mathrm{Cbl}$ ), phosphoric acid, trichloroacetic acid (TCA), tris-base, sodium phosphate monobasic and sodium phosphate dibasic were purchased from Sigma-Aldrich (Canada Ltd, Oakville, ON, CANADA). HPLC-gradient grade methanol was obtained from Fisher (Fair Lawn, NJ, USA). One $\mathrm{mL}-\mathrm{TB}$ (Tuberculin) syringes were purchased from BD (Franklin Lakes, NJ, USA), PVDF (polyvinylidene difluoride) syringe filters (units) $0.45 \mu \mathrm{m}$ were manufactured by National Scientific Company (Rockwood, TN, USA) and $1.5 \mathrm{~mL}$ boil-proof microtubes were distributed by Ultident Scientific (Montréal, QC, Canada). Filter sheets $0.2 \mu \mathrm{m}$ were manufactured products of Pall Corporation (Ann Arbor, MI, USA).

\section{Sample preparation}

Bovine liver was purchased from a slaughterhouse (Viande Giroux, East Angus, QC, Canada), collected immediately after slaughter and transported on ice to the laboratory within 50 minutes. Upon arrival at the laboratory, a portion of the liver was homogenized on ice in 4.5 volumes $(w / v)$ of cold distilled water. The homogenates were centrifuged at $750 \mathrm{~g}$ for 10 minutes at $4^{\circ} \mathrm{C}$. The supernatants were then aliquoted $(1 \mathrm{~mL})$ and stored in microcentrifuge tubes at $-80^{\circ} \mathrm{C}$. The remaining hepatic tissue was cut in pieces, immediately frozen into liquid nitrogen and stored at $-80^{\circ} \mathrm{C}$ until use. On the day of analysis, a small volume $(\sim 30 \mu \mathrm{L})$ was used to measure protein concentration by the method of Bradford using bovine serum albumin as standard (Bio-Rad protein assay kit, Bio-Rad Laboratories (Canada) Ltd, Mississauga ON, Canada). Then, the remainder of the homogenate was diluted with distilled water to obtain the chosen protein concentration for the assay. Hepatic tissue was also obtained by liver biopsy performed on 6 lactating dairy cows, $64 \pm 3$ days after calving, under local anesthesia and ultrasound guidance to minimize the hemorrhagic risks as described by Graulet et al. [8]. The procedure was approved by the Institutional Committee on Animal Care of the Dairy and Swine Research and Development Centre, Agriculture and Agri-Food Canada, Sherbrooke, QC, Canada. Tissues were immediately frozen into liquid nitrogen and stored at $-80^{\circ} \mathrm{C}$ until use. Homogenates from frozen tissues (biopsies from dairy cows and tissue from the slaughterhouse) were prepared as described above.

\section{Preparation of standards}

A stock solution of methylmalonyl-CoA (1 mM) was prepared in $300 \mathrm{mM}$ of tris-phosphate buffer, $\mathrm{pH}$ 7.5; this solution was aliquoted and kept at $-30^{\circ} \mathrm{C}$. Thus, calibration solutions of methylmalonyl-CoA could be prepared by diluting the stock solution in $100 \mathrm{mmol} / \mathrm{L}$ phosphate buffer, $\mathrm{pH}$ 4.0. The succinyl-CoA calibration solutions (stock, $500 \mu \mathrm{M}$ ) were prepared in $200 \mathrm{mmol} / \mathrm{L}$ phosphoric acid, $\mathrm{pH} 1.8$, aliquoted and stored at $-30^{\circ} \mathrm{C}$. A solution of AdoCbl (1 mM) for the determination of total enzyme activity was also prepared in distilled water, protected against light inactivation and stored at $-30^{\circ} \mathrm{C}$.

\section{Liquid chromatography}

The HPLC analyses were carried out on an Agilent technology system consisting of two proStar 210 pumps, 320 UV detector and 420 AutoSampler. The Agilent Poroshell 120 EC-C18, $2.7 \mu \mathrm{m}, 3.0 \mathrm{~mm} \times 100 \mathrm{~mm}$ threaded column was heated at $40^{\circ} \mathrm{C}$ with a HPLC column heater Croco-cil ${ }^{\circ}$. The assay reaction mixture for total MCM activity contained, in a total volume of $150 \mu \mathrm{L}, 16$ to $333 \mu \mathrm{g}$ of liver homogenate protein $(60 \mu \mathrm{L}), 30 \mu \mathrm{L}$ of AdoCbl $(1 \mathrm{mM})$, and $60 \mu \mathrm{L}$ of methylmalonyl-CoA $(1 \mathrm{mM})$. The liver 
homogenate was first incubated with AdoCbl for 5 minutes at $37^{\circ} \mathrm{C}$ before initiating the enzyme reaction by adding methylmalonyl-CoA. The tubes were again incubated at $37^{\circ} \mathrm{C}$ for 0 to 30 minutes and the reaction was stopped by adding $50 \mathrm{~mL}$ of trichloroacetic acid (TCA; $100 \mathrm{~g} / \mathrm{L}$ ). The tubes were centrifuged at $13000 \mathrm{~g}$ for $1 \mathrm{~min}$. The supernatant was collected and filtered in amber glass vials through a $0.45 \mu \mathrm{m}$ syringe-operated filter units. A volume of $20 \mu \mathrm{L}$ of sample was injected in the HPLC system. Blanks were included in every run.

The reverse phase column was equilibrated with $56 \%$ solvent A (100 mM acetic acid in $100 \mathrm{mM}$ of sodium phosphate buffer, $\mathrm{pH} 7.0)$ and $44 \%$ solvent $\mathrm{B}(18 \% \mathrm{v} / \mathrm{v}$ methanol in solvent A). The method consisted in a linear methanol gradient: $0-3 \min (44 \%$ solvent B); $3-9$ min (44 - 75\%); 9 - $12 \min (75-100 \%) ; 12-17 \min (100-$ $44 \%$ ); and 17 - $35 \mathrm{~min}(44 \%)$ with a flow rate of $0.2 \mathrm{~mL} /$ min. The solvent A was filtered through $0.2 \mu \mathrm{m}$ membrane. The compounds were detected at $254 \mathrm{~nm}$.

\section{Validation of the method}

Method validation was performed according to guidelines set by the United States Food and Drug Administration (FDA) for bioanalytical method validation [32]. Hence, linearity, specificity, low limit of quantitation (LLOQ), recovery, intra- and inter-day accuracy and precision, and stability of the analyte during sample storage and processing procedures were determined.

\section{Linearity and sensitivity}

The lowest standard on the calibration curve has been determined by testing a range from 0.48 to $500 \mu \mathrm{M}$. Each concentration was prepared in duplicate and the test was repeated once. Calibration curves were built by plotting peak areas versus concentrations of methylmalonyl-CoA or succinyl-CoA, and the regression equations were calculated. Low limits of detection (LOD) were determined when electropherograms produced peaks with a signal-tonoise ratio $(\mathrm{S} / \mathrm{N})$ of 3 at $254 \mathrm{~nm}$ wavelength. The LLOQ were determined based on the $\mathrm{S} / \mathrm{N}(>5), \mathrm{CV}(<20 \%)$ and accuracy $(>80 \%)$. Linearity of the reaction according to enzyme concentrations obtained by different dilutions of the liver extract homogenates was also determined. The amounts of protein tested were: $16,26,33,52,66,83,104$, 166, 208 and $333 \mu \mathrm{g}$. The linearity of the enzyme reaction versus incubation time $(0,5,10,15,20,25,30$ and $40 \mathrm{~min})$ was also measured.

\section{Specificity}

The specificity of the method for dilutions of methyl malonyl-CoA and succinyl-CoA was tested on samples spiked and not spiked with known standards.

\section{Method precision and recovery}

The precision of the instruments was checked using samples injected repeatedly $(n=45)$. Forty-five replicates of homogenates providing $66 \mu \mathrm{g}$ of protein were assayed over nine days. The intra- and inter-assay precisions were determined using the CV. Separate runs of three levels of standards $($ Low $=7.8 \mu \mathrm{M}$; Middle $=62.5 \mu \mathrm{M}$ and High $=$ $500 \mu \mathrm{M})$ were made. The accuracy (\%) of the method was expressed by [(Measured concentration)/(Nominal concentration)] $\times 100$.

The recovery of succinyl-CoA was studied by addition of a known amount of standard $(75 \mu \mathrm{M})$ to prequantified samples after stopping the reaction. Briefly, a volume of $50 \mu \mathrm{L}$ of TCA was added to the reaction mixture to stop the reaction and after centrifugation, $170 \mu \mathrm{L}$ of the supernatant was collected. This volume was completed to $200 \mu \mathrm{L}$ by adding $30 \mu \mathrm{L}$ of standard (stock, $500 \mu \mathrm{M}$ ). Recovery was performed by comparing the analytical results for extracted samples at the three concentrations tested (33, 66 and $166 \mu \mathrm{g}$ of protein) with standards that represent $100 \%$ recovery. Recovery $(\%)=[($ Measured concentration in spiked sample - Measured concentration in non-spiked sample)/Standard concentration] $\times 100$.

\section{Stability study}

The amounts of succinyl-CoA formed using frozen extracts prepared from fresh liver or extracts prepared from tissue snapped in liquid nitrogen were compared and the CV between the two modes of preparation was calculated. The percentages of difference between days of runs were also calculated as follow: $\%$ difference day vs day $_{\mathrm{n}+1}=\left[\right.$ (Concentration on day $_{\mathrm{n}}$ - Concentration on day $\left._{n+1}\right) /$ Concentration on day $\left.\left._{n}\right)\right] \times 100$. These runs included two vials of a known concentration of the standard succinyl-CoA $(75 \mu \mathrm{M})$ and two vials of standards (succinyl-CoA + methylmalonyl-CoA, $125 \mu \mathrm{M}$ each) mixed to check the reliability of the method. The stability of standard and sample solutions when re-injected after being left at room temperature for more than 24 hours was evaluated to detect if the time spent in the autosampler affected the measurements.

\section{Pharmacokinetic study}

As component of ongoing studies to validate the HPLC method for the evaluation of MCM activity in bovine liver extract, pharmacokinetics of MCM was studied. The kinetics of MCM was established by testing increasing concentrations of substrate, methylmalonyl-CoA: 6.25, $12.5,25,50,100,200$ and $400 \mu \mathrm{M}$. The initial amount of protein (enzyme) and the time of incubation were $66 \mu \mathrm{g}$ and 30 min respectively.

Holomutase and total specific activities were measured in liver tissue obtained by biopsy from six lactating dairy cows. Testing increasing concentrations of protein allowed 
Table 1 Limits of quantification of succinyl-CoA and methylmalonyl-CoA

\begin{tabular}{cccc}
\hline Succinyl-CoA & & & \\
\hline $\begin{array}{c}\text { Nominal } \\
\text { concentration }(\mu \mathrm{M})\end{array}$ & $\begin{array}{c}\text { Mean calculated } \\
\text { concentration }(\mu \mathrm{M})\end{array}$ & $\begin{array}{c}\mathrm{CV} \% \\
\mathrm{n}=4\end{array}$ & Accuracy $\%$ \\
7.81 & 6.74 & 10.38 & 86.33 \\
15.62 & 15.35 & 1.22 & 98.28 \\
31.25 & 30.72 & 1.20 & 98.32 \\
62.5 & 63.98 & 1.65 & 102.37 \\
125 & 125.71 & 0.40 & 100.57 \\
250 & 249.47 & 0.15 & 99.79 \\
500 & 497.58 & 0.34 & 99.52 \\
\hline Methylmalonyl-CoA & & & \\
\hline Nominal & Mean calculated & CV\% & Accuracy $\%$ \\
concentration $(\mu \mathrm{M})$ & concentration $(\mu \mathrm{M})$ & $\mathrm{n}=4$ & \\
15.62 & 15.33 & 1.34 & 98.12 \\
31.25 & 31.20 & 0.10 & 99.85 \\
62.5 & 63.65 & 1.28 & 101.83 \\
125 & 125.55 & 0.31 & 100.44 \\
250 & 249.47 & 0.15 & 99.79 \\
500 & 495.82 & 0.59 & 99.16 \\
\hline
\end{tabular}

The calculated concentrations are compared to nominal concentrations and the coefficients of variation (CV\%) are presented. Solvent $A$ of the mobile phase contained $0.1 \mathrm{M}$ sodium phosphate buffer $(\mathrm{pH} 7)$ with $100 \mathrm{mM}$ of acetic acid. Solvent B consisted of $18 \%$ methanol in solvent $\mathrm{A}$. The column temperature was $40^{\circ} \mathrm{C}$. us to find that using $30-40 \mu \mathrm{g}$ of protein was sufficient to obtain reproducible results from these homogenates.

\section{Data analysis}

Means, standard errors and CV were calculated using Excel software. In figures, values are means, with their standard errors (SE) represented by vertical bars.

\section{Results \\ Method validation \\ Linearity and sensitivity}

The lowest concentrations of succinyl-CoA and methyl malonyl-CoA measured with precision were respectively $6.74 \mu \mathrm{M}$ and $15.33 \mu \mathrm{M}$ (Table 1). However the LOD were about $1 \mu \mathrm{M}$ for succinyl-CoA and $2 \mu \mathrm{M}$ for methyl malonyl-CoA. Figure 1 shows the typical chromatogram of a mixture of methylmalonyl-CoA $(\mathrm{RT}=10.4 \mathrm{~min})$ and succinyl-CoA ( $\mathrm{RT}=12.3 \mathrm{~min}$ ). Calibration curves were plotted from LLOQ of each standard to $500 \mu \mathrm{M}$. The CV for the seven calibration standard points of succinyl-CoA ranged from 0.15 to $10.38 \%$ with accuracy varying from 86 to $102.37 \%$ (Table 1). The curve of methylmalonyl-CoA (Additional file 1: Figure S1) had six points with CV of 0.10 to $1.34 \%$ and accuracy varying from 98.12 to $101.83 \%$ (Table 1).

System suitability parameters such as theoretical plate number, relative retention time, tailing, selectivity and capacity factors between methylmalonyl-CoA and succinylCoA presented in Additional file 2: Table S1 were checked

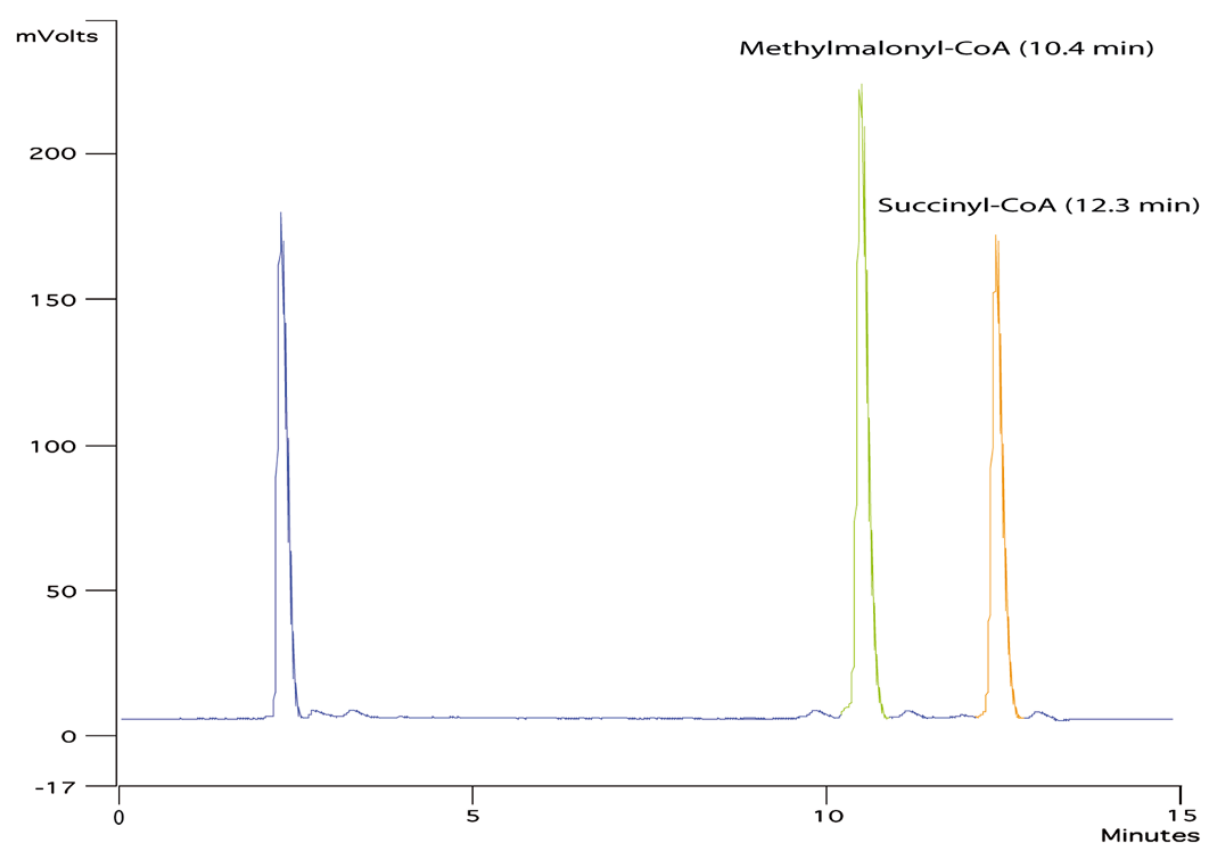

Figure 1 Electropherograms of a solution of methylmalonyl-CoA and succinyl-CoA. Chromatograms were obtained using $0.1 \mathrm{M}$ sodium phosphate buffer ( $\mathrm{pH}$ 7) containing $100 \mathrm{mM}$ of acetic acid, as solvent $\mathrm{A}$ of the mobile phase, and 18\% of methanol in solvent $\mathrm{A}$ being the solvent B. The column temperature was $40^{\circ} \mathrm{C}$. 
in order to verify the system, method and column performance. The resolution between methylmalonyl-CoA and succinyl-CoA is not less than 2 and tailing factor for each peak is not more than 2 . The plate count is also greater than 2000.

The concentration (y) of succinyl-CoA formed was evaluated using the calibration curve $\left(y=28564 x+35388 ; R^{2}=\right.$ $0.9999)$, where peak area is $x$. The conditions under which the conversion of methylmalonyl-CoA into succinyl-CoA was linear with respect to incubation time and the amount of liver crude extract used were studied. The formation of succinyl-CoA increased linearly when the amounts of protein in the assay increased from 16 to $66 \mu \mathrm{g}$ (Figure 2A). The rate of the formation of succinyl-CoA slowed down from 66 to $208 \mu \mathrm{g}$ and even declined when a greater amount of protein was used (Additional file 3: Figure S2). The interconversion of methylmalonyl-CoA into succinylCoA, as illustrated in Figures 2B and Additional file 4: S3, followed a quadriphasic time course: an ascending phase (0-20 $\mathrm{min})$, a slow-down phase (20-25 min), a plateau (25$30 \mathrm{~min}$ ) and a decline (30-40 min). Hydrolysis or degradation of Coenzyme A (CoA) esters occurred during the process and Additional file 4: Figure S3 also shows the free CoA concentration. Both enzyme activity and hydrolysis decreased the amount of methylmalonyl-CoA during the time of incubation. Between 25 and 30 minutes, the concentration of methylmalonyl-CoA did not change drastically and was around $130 \mu \mathrm{M}$; accordingly, a reduction in the production of succinyl-CoA was not due to a depletion of methylmalonyl-CoA.

\section{Specificity, recovery and analyte stability}

Specificity of the method was assessed by comparison of non-spiked samples with spiked ones. Both samples (nonspiked and spiked) had the same amount of protein. There was not any interfering peak from liver extract at the
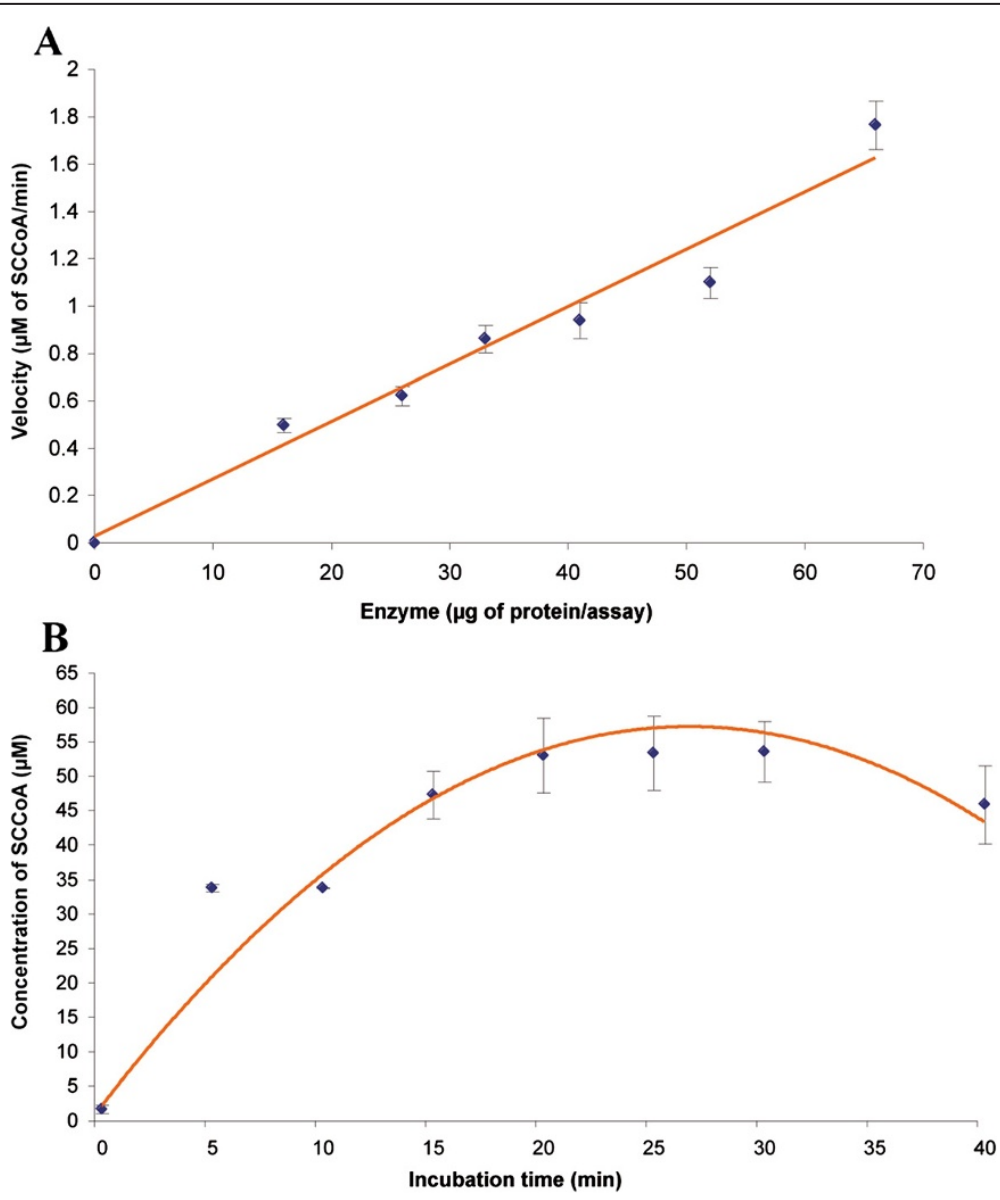

Figure 2 Formation of succinyl-CoA according to protein amount or time of incubation. A) Rate of formation of succinyl-CoA per min according to the amount of protein used in the assay after $30 \mathrm{~min}$ of incubation at $37^{\circ} \mathrm{C}$. Each amount of protein was tested 4 times and the initial concentrations of AdoCbl and MMCoA were $200 \mu \mathrm{M}$ and $400 \mu \mathrm{M}$ respectively. B) Concentration of succinyl-CoA ( $\mu \mathrm{M})$ formed by $66 \mu \mathrm{g}$ of protein at $37^{\circ} \mathrm{C}$ as a function of incubation time (expressed in minutes). The initial concentration of AdoCbl and MMCoA were $200 \mu \mathrm{M}$ and $263 \mu \mathrm{M}$ respectively. Tests were done twice at 5, 10 and 40 minutes, five times at 0 minute and 8 times at 15, 20,25 and 30 minutes. Values are presented as the mean \pm SE (Standard Error). 
retention times corresponding to methylmalonyl-CoA or succinyl-CoA. The best recovery rate was observed using $66 \mu \mathrm{g}$ of protein (Table 2). Stability of liver extract was studied to define optimal conditions for the analysis. Storage (frozen homogenate of fresh tissue or fresh homogenate of tissue snapped in liquid nitrogen) and processing conditions were studied. When homogenates were prepared from nitrogen-snapped frozen liver pieces, concentrations of the analyte were similar to those measured on homogenates prepared using fresh tissue and frozen at $-80^{\circ} \mathrm{C}$. The $\mathrm{CV}$ between the two types of homogenates was $8.21 \%$. The analyte was also stable in liver crude extract for three frozen/thawed cycles when stored at $-20^{\circ} \mathrm{C}$ and thawed to room temperature $(\mathrm{CV}=7.30 \%)$. The \% differences between two consecutive days (day 1 vs day 2; day 2 vs day 3 ) for fresh liver homogenates and homogenates of nitrogensnapped liver tissue were $6.3 ; 7.7 \%$ and $5.8 ; 11.6 \%$ respectively. The inter-day CVs were 7.30 and $9.43 \%$, respectively for the two types of homogenates. The quality control in each run reveals that the system is reliable with an accuracy of $88.76 \%$ (Table 2). As shown in Table 3, samples remained stable for at least 45 hours at room temperature with CVs varying from 4.55 to $9.22 \%$. Similarly, when used three consecutive days, succinyl-CoA standard remained stable with an accuracy varying from $85 \%$ to $104 \%$ (Table 3). Data in Additional file 5: Table S2 strengthens the precision data of the method with accuracies varying from $84 \%$ to $93 \%$ for three control concentrations of methylmalonyl-CoA.

\section{Pharmacokinetics}

Figure 3 presents the velocity of MCM versus increasing concentration of substrate after 30 minutes of incubation at $37^{\circ} \mathrm{C}$. Apparent kinetic parameters for $\mathrm{MCM}$ ( $\mathrm{Km}$ and Vmax) were determined using $66 \mu \mathrm{g}$ of protein and $200 \mu \mathrm{M}$ of AdoCbl, but increasing concentrations of methylmalonyl-CoA (4.69-300 $\mu \mathrm{M})$. Values for Vmax $(1.1544 \mu \mathrm{M}$ per min) and $\mathrm{Km}(49.126 \mu \mathrm{M})$ were calculated from Lineweaver-Burk representation and Eadie-

Table 2 Recovery and stability of succinyl-CoA according to sample storage condition

\begin{tabular}{|c|c|c|c|c|c|}
\hline \multicolumn{6}{|c|}{ Recovery data } \\
\hline Level of protein tested $(\mu \mathrm{g})$ & Level of standard added $(\mu \mathrm{M})$ & $\mathrm{n}$ & Recovery\% & & CV\% \\
\hline 33 & 75 & 4 & 73.79 & & 12.61 \\
\hline 66 & 75 & 6 & 83.97 & & 6.46 \\
\hline 166 & 75 & 3 & 70.83 & & 14.72 \\
\hline \multicolumn{6}{|l|}{ Sample storage stability } \\
\hline & $n$ & Mean Conc $(\mu \mathrm{M})$ & CV\% & CV\% inter-day & $\%$ difference \\
\hline \multicolumn{6}{|l|}{ Fresh liver } \\
\hline day 1 & 5 & 60.88 & 1.72 & & day 1 vs day $2: 7.7$ \\
\hline day 2 & 5 & 56.20 & 0.90 & & day 2 vs day 3: 6.3 \\
\hline \multirow[t]{2}{*}{ day 3} & 5 & 52.64 & 3.25 & & day 1 vs day 3: 13.5 \\
\hline & 15 & & & 7.30 & \\
\hline \multicolumn{6}{|l|}{ Nitrogen snapped Liver } \\
\hline day 1 & 5 & 58.72 & 5.05 & & day 1 vs day 2: 11.6 \\
\hline day 2 & 5 & 51.93 & 8.21 & & day 2 vs day 3: 5.8 \\
\hline \multirow[t]{2}{*}{ day 3} & 5 & 48.94 & 1.39 & & day 1 vs day 3: 16.7 \\
\hline & 15 & & & 9.43 & \\
\hline Fresh vs Nitrogen & 30 & 54.89 & & 8.21 & 6 \\
\hline Control standard $75 \mu \mathrm{M}$ & & & & & Accuracy\% \\
\hline day 1 & 2 & 60.84 & 17.99 & & \\
\hline day 2 & 2 & 69.80 & 10.82 & & \\
\hline day 3 & 2 & 68.70 & 1.06 & & \\
\hline day 4 & 2 & 64.69 & 0.51 & & \\
\hline day 5 & 2 & 65.83 & 3.23 & & \\
\hline \multirow[t]{2}{*}{ day 6} & 2 & 69.57 & 6.84 & & \\
\hline & 12 & 66.57 & & 8.18 & 88.76 \\
\hline
\end{tabular}

The best recovery ratio was observed with $66 \mu \mathrm{g}$ of protein. The results of storage stability correspond to the mean concentration of SSCoA ( $\mu \mathrm{M}$ ) formed by $66 \mu \mathrm{g}$ of protein over $30 \mathrm{~min}$ of incubation at $37^{\circ} \mathrm{C}$ in presence of $200 \mu \mathrm{M}$ of AdoCbl and $400 \mu \mathrm{M}$ of MMCoA. Two vials of a known concentration of the standard $(75 \mu \mathrm{M})$ were included as quality control. 
Table 3 Stability of succinyl-CoA after completion of experiences and quality control test with succinyl-CoA standard solutions

\begin{tabular}{|c|c|c|c|c|c|}
\hline \multicolumn{6}{|c|}{ Post-process stability } \\
\hline Sample ID & Injection count & Time after the first injection (hours) & Mean concentration of SSCoA $(\mu \mathrm{M})$ & \multicolumn{2}{|c|}{ CV\% inter-injection } \\
\hline Bovine-liver-1 & 2 & 33 & 33.74 & \multicolumn{2}{|c|}{9.22} \\
\hline Bovine-liver-2 & 2 & 39 & 65.59 & \multicolumn{2}{|c|}{7.25} \\
\hline Bovine-liver-3 & 2 & 40 & 56.11 & \multicolumn{2}{|c|}{6.67} \\
\hline Bovine-liver-4 & 2 & 45 & 51.20 & \multicolumn{2}{|c|}{4.55} \\
\hline Standard (SSCoA) & & High Qc & Middle Qc & Low Qc-2 & Low Qc-1 \\
\hline Nominal value & & $500 \mu \mathrm{M}$ & $62.5 \mu \mathrm{M}$ & $7.8 \mu \mathrm{M}$ & $3.9 \mu \mathrm{M}$ \\
\hline \multicolumn{6}{|l|}{ day 1} \\
\hline & & 485.14 & 59.99 & 7.11 & 3.53 \\
\hline & & 415.51 & 63.46 & 7.12 & 3.98 \\
\hline & & 414.23 & 51.80 & 10.20 & 4.29 \\
\hline & Mean $(n=3)$ & 438.29 & 58.42 & 8.15 & 3.93 \\
\hline & $\mathrm{CV} \%$ & 9.26 & 10.25 & 21.87 & 9.67 \\
\hline \multicolumn{6}{|l|}{ day 2} \\
\hline & & 441.52 & 67.30 & 7.86 & 3.75 \\
\hline & & 435.70 & 56.49 & 7.97 & 3.72 \\
\hline & & 433.57 & 56.71 & 7.86 & 3.51 \\
\hline & Mean $(n=3)$ & 436.93 & 60.16 & 7.90 & 3.66 \\
\hline & $\mathrm{CV} \%$ & 0.94 & 10.27 & 0.83 & 3.61 \\
\hline \multicolumn{6}{|l|}{ day 3} \\
\hline & & 401.95 & 64.41 & 8.39 & 3.52 \\
\hline & & 405.45 & 64.14 & 8.48 & 3.67 \\
\hline & & 403.39 & 62.29 & 8.53 & 3.48 \\
\hline & Mean $(n=3)$ & 403.60 & 63.61 & 8.47 & 3.56 \\
\hline & CV\% & 0.44 & 1.82 & 0.86 & 2.79 \\
\hline CV\% inter-days $(n=9)$ & & 6.23 & 8.08 & 11.33 & 7.20 \\
\hline Accuracy\% & & 85.25 & 97.17 & 104.75 & 95.29 \\
\hline
\end{tabular}

The post-process stability study used $66 \mu \mathrm{g}$ of protein over $30 \mathrm{~min}$ of incubation at $37^{\circ} \mathrm{C}$ in presence of $200 \mu \mathrm{M}$ of AdoCbl and $400 \mu \mathrm{M}$ of MMCoA. The quality control (Qc) study used four concentrations of the standard succinyl-CoA. The calculated accuracies varied from $85 \%$ to $104 \%$.

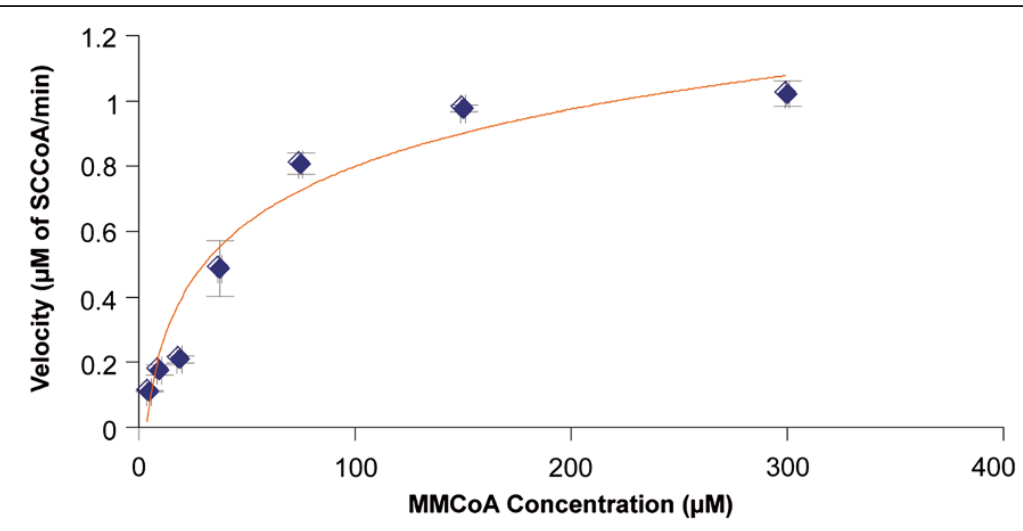

Figure 3 Velocity of MCM versus increasing concentration of substrate after $\mathbf{3 0} \mathrm{min}$ of incubation at $37^{\circ} \mathrm{C}$. The results are based on the mean concentration of succinyl-COA (SCCOA) for 2 assays; we tested 7 substrate (methylmalonyl-COA, MMCoA) concentrations (4.69-300 $\mu \mathrm{M})$ using $66 \mu \mathrm{g}$ of protein and $200 \mu \mathrm{M}$ of AdoCbl. Each concentration level was duplicated in each assay. Error bars are the Standard Error (SE). 
Hofstee transformation of the data points respectively. When reported per mg of protein, Vmax was $17.5 \mu \mathrm{M}$ of succinyl-CoA per minute per milligram of protein or $3.5 \mathrm{nmol} / \mathrm{min} / \mathrm{mg}$ protein if the volume $(200 \mu \mathrm{L})$ of reaction medium is taken into account. Mean specific activity of MCM in a bovine liver obtained from a slaughterhouse was $5.9 \pm 0.4 \mathrm{nmol} / \mathrm{min} / \mathrm{mg}$ protein (Table 4 ).

The holomutase specific activity in liver of six lactating dairy cows at the same stage of lactation and fed the same diet represented between 2 and $5 \%$ of the total activity, it varied from $0.352 \pm 0.002$ to $0.68 \pm 0.01 \mathrm{nmol} / \mathrm{min} /$ $\mathrm{mg}$ protein whereas the total specific activity varied from $12 \pm 1$ to $15.4 \pm 0.6 \mathrm{nmol} / \mathrm{min} / \mathrm{mg}$ protein (Table 5 ).

\section{Discussion}

Several methods for measuring MCM activity have been published. Some of these methods used radioactive isotopes [9-17], others are not [8,18-22]. Among these latter methods, evidence suggests that HPLC is more reproducible and accurate for measurement of small amounts of succinyl-CoA [29]. Validated data for the RP-HPLC according to criteria from FDA guidelines for bioanalytical method validation [32] are provided.

Bovine liver was chosen because of the importance of gluconeogenesis for ruminant animal, one of the major substrate being propionate [33]. A series of studies were performed to investigate the interconversion of methylmalonyl-CoA into succinyl-CoA in this tissue. As can be seen from this study, the amounts of succinyl-CoA formed increased with time until 20 minutes of incubation and the reaction is completed after half-hour of incubation. Conversion of methylmalonyl-CoA into succinylCoA also increased when increasing the amount of protein until $208 \mu \mathrm{g}$. It was also observed that reaction

Table $\mathbf{4}$ Specific activity of MCM measured in liver
obtained from slaughterhouse
\begin{tabular}{lccc}
\hline Runs & $\begin{array}{c}\text { Total SA } \pm \text { SD }(\mathbf{n}=\mathbf{5}) \\
\text { nmole/min/mg protein }\end{array}$ & $\begin{array}{c}\text { CV\% intra-run } \\
(\mathbf{n}=\mathbf{5})\end{array}$ & $\begin{array}{c}\text { CV\% inter-run } \\
(\mathbf{n}=\mathbf{4 5})\end{array}$ \\
\hline Run 1 & $5.563 \pm 0.200$ & 3.60 & \\
Run 2 & $6.569 \pm 0.333$ & 5.07 & \\
Run 3 & $6.015 \pm 0.281$ & 4.68 \\
Run 4 & $6.465 \pm 0.378$ & 5.85 \\
Run 5 & $6.234 \pm 0.502$ & 8.05 \\
Run 6 & $5.558 \pm 0.166$ & 2.98 \\
Run 7 & $6.150 \pm 0.106$ & 1.72 \\
Run 8 & $5.677 \pm 0.051$ & 0.90 \\
Run 9 & $5.317 \pm 0.173$ & 3.25 \\
Mean SA & $5.950 \pm 0.44$ & & 7.40 \\
\hline
\end{tabular}

Assays were performed in presence of $200 \mu \mathrm{M}$ of AdoCbl and $400 \mu \mathrm{M}$ of MMCoA. Incubation was conducted at $37^{\circ} \mathrm{C}$ for $30 \mathrm{~min}$. The amounts of protein used in the assays were $66 \mu \mathrm{g}$. Specific activities (SA) are expressed as nmoles of succinyl-CoA/min/mg protein. Standard deviation (SD) and coefficients of variation (CV\%) are also presented.
Table 5 Specific activity of MCM measured in liver of dairy cows at their peak of lactation

\begin{tabular}{ccccc}
\hline Dairy cows & $\begin{array}{c}\text { Total SA } \pm \text { SD }(\mathbf{n = 3}) \\
\mathbf{n m o l e} / \mathbf{m i n} / \mathbf{m g}\end{array}$ & $\begin{array}{c}\text { CV\% } \\
\text { Holo SA } \pm \text { SD }(\mathbf{n}=3) \\
\mathbf{n m o l e} / \mathbf{m i n} / \mathbf{m g}\end{array}$ & $\mathbf{C V} \%$ \\
\hline 1 & $15.249 \pm 0.543$ & 3.56 & $0.467 \pm 0.035$ & 7.57 \\
2 & $12.027 \pm 0.973$ & 8.09 & $0.561 \pm 0.036$ & 6.37 \\
3 & $15.415 \pm 0.631$ & 4.10 & $0.489 \pm 0.012$ & 2.46 \\
4 & $13.091 \pm 0.397$ & 3.03 & $0.513 \pm 0.046$ & 8.88 \\
5 & $14.552 \pm 0.881$ & 6.05 & $0.352 \pm 0.002$ & 4.65 \\
6 & $12.714 \pm 0.405$ & 3.18 & $0.676 \pm 0.014$ & 2.09 \\
\hline
\end{tabular}

Assays were performed in presence of $200 \mu \mathrm{M}$ of AdoCbl and $400 \mu \mathrm{M}$ of MMCoA. Incubation was conducted at $37^{\circ} \mathrm{C}$ for $30 \mathrm{~min}$. The amounts of protein used in the assays were $40 \mu \mathrm{g}$. Specific activities (SA) are expressed as nmoles of succinyl-CoA/min/mg protein. Standard deviation (SD) and coefficients of variation (CV\%) are also presented.

rates increased with increasing amounts of substrate. The method is specific; its reproducibility depends on the initial concentrations of the enzyme in the studied tissue. The reproducibility of the method published by Gaire and colleagues was greatly improved by bringing the inter-day CV from $12.16 \%$ [29] to $7.30 \%$ (present study). After completion of experiences, analyte remained stable and an analytical run could be reanalyzed in the case of instrument failure.

Analytes were considered stable in mouse [34] and human [35] plasma when the difference of concentration was less than $15 \%$ between freshly prepared samples and samples tested under various conditions $[34,35]$. In the present study, difference between fresh homogenates prepared from liver biopsies snapped in liquid nitrogen and frozen homogenates prepared from fresh tissue $(6 \%)$ was inferior to $15 \%$. Similarly, after 3 frozen/thawed cycles, this difference was low for two consecutive days. Accordingly, present results suggested that the analytes are stable during sample storage, extraction and chromatography processes for MCM in liver samples. However repeated frozen/thawed cycles of homogenates should be avoided because in spite of low CV, the average concentration numerically decreased from day 1 to day 3 .

The estimated $\mathrm{Km}$ of the enzyme MCM calculated in the present study is lower than in previous reports. Willard and Rosenberg measured a $\mathrm{Km}$ value of $70 \mu \mathrm{M}$ for the crude human MCM in fibroblast extracts [36]. A comparable $\mathrm{Km}(60 \mu \mathrm{M})$ has been measured by Taoka and coworkers with human recombinant MCM [7]. Higher values have been reported for human (300 to $350 \mu \mathrm{M})$ and mouse hepatic MCM $(270 \mu \mathrm{M})$ using a radiolabeled methodology $[37,38]$. To determine MCM activity, Taoka et al. used the spectrophotometric detection of the CoA resulting from the hydrolysis of the succinyl-CoA. Results from the present study are lower than the mean $\mathrm{Km}$ value previously reported by our team $(160 \mu \mathrm{M})$ in liver of lactating dairy cows [8], using the spectrometric assay method 
described by Taoka et al. [7]. Using a HPLC method, Gaire et al. measured a total specific activity of hepatic MCM in rat of $6.15 \mathrm{nmol} / \mathrm{min} / \mathrm{mg}$ protein [29] whereas the radiometric method gave a value of $1.9 \mathrm{nmol} / \mathrm{min} / \mathrm{mg}$ protein for the same sample [29]. The discrepancies observed may not only be species-dependent, especially ruminant versus non-ruminant, but also due to the method limitations.

Total specific activity in liver of dairy cows previously reported [8] using mitochondrial extract averaged $10.8 \mathrm{nmol} / \mathrm{min} / \mathrm{mg}$ protein and was in the same range than the present data for lactating dairy cows. Total specific activity of MCM in a liver obtained from a slaughterhouse $(5.95 \mathrm{nmol} / \mathrm{min} / \mathrm{mg}$ protein) was similar to published values obtained in rat $[29,30]$, mouse [38] and sheep [23] livers.

In ruminants, methylmalonyl-CoA is involved in gluconeogenesis [27]. Propionate is the major substrate for gluconeogenesis in dairy cows [6], and MCM is a key enzyme in the metabolism of propionate [39], essential to its entry into Krebs cycle and subsequent gluconeogenesis. Amongst all ruminants, efficient gluconeogenesis is most important in high-producing dairy cows because it is the major pathway for maintaining adequate glucose supply to the mammary gland for milk production [40]. In the present study, it was not known whether the liver bought from a slaughterhouse was from a steer, a heifer or a lactating or dry cow. Therefore, differences observed in specific activities between the liver obtained from the slaughterhouse and liver tissues obtained from lactating dairy cows at their peak of lactation are likely due to the physiological stage of the animal. Nevertheless, it cannot be ruled out that difference in the mode of preparation (treated within less than 1 hour after slaughter or frozen immediately after biopsy) could affect MCM activity measurements.

\section{Conclusions}

Recently, a capillary electrophoresis method to measure MCM activity has been published [30]. We took an interest in that method for its short elution time $(10 \mathrm{~min})$ but the separation buffer needed $15 \mathrm{mM}$ of sodium dodecyl sulfate (SDS) [30]. SDS is a highly effective surfactant [41]. In routine applications, dedication of one capillary to each application (particularly if surfactants are present) is recommended [42]. Furthermore, the high-concentration surfactant decreases both the separation efficiency and the reproducibility of the electrophoretic capillary method [31]. Indeed, as regards the signal-to-noise ratio of 3, the authors had a LOD of $3.4 \mu \mathrm{M}$ [30] suggesting that present RP-HPLC is more sensitive with a LOD of $1 \mu \mathrm{M}$ for the succinyl-CoA. As described in the materiel and method section, a centrifugation step after protein precipitation using TCA improved repeatability as compared to previous published results [29]. In addition, $100 \mathrm{mM}$ of acetic acid in mobile phase improved the separation of residual substrate (methylmalonyl-CoA) and product (succinyl$\mathrm{CoA}$ ), and consequently contributed to improve system suitability. Finally the method is specific, accurate, precise and more sensitive than the previously published ones for the quantitative determination of methylmalonyl-CoA and succinyl-CoA in liver. It can be easily implemented into routine practice. This comprehensively validated method will allow studying the effects of stages of lactation, diet composition, and physiology in cattle. It is ideal for analysis of MCM activity and hence a tool to monitor cobalamin status in experimental and clinical studies.

\section{Additional files}

Additional file 1: Figure S1. Calibration curve of methylmalonyl-CoA. The linearity range was 3.9 to $500 \mu \mathrm{M}$. Area under of the curve (AUC) is presented as a function of methylmalonyl-CoA concentration (MMCoA Conc) expressed in $\mu \mathrm{M}$.

Additional file 2: Table S1. System suitability parameters. Values in the results column are calculated according to Figure $1 . \mathrm{t} 1=$ retention time of the peak of methylmalonyl-CoA. t2: retention time of the peak of succinyl-CoA. w1 = Width at half height for the peak of methylmalonylCoA. w2: width at half for the peak of succinyl-COA. L: length of the column in centimetres. t0: time of unretained peak. tL: retention time of leading edge at $5 \%$ height. tT: retention time of tailing edge at $5 \%$ height.

Additional file 3: Figure S2. Velocity for increasing amounts of protein after 30 minutes of incubation at $37^{\circ} \mathrm{C}$. Concentration of succinyl-CoA formed $(\mu \mathrm{M})$ per min according to the quantity of protein used in the assay $(0-333 \mu \mathrm{g})$ in presence of $200 \mu \mathrm{M}$ of AdoCbl and $400 \mu \mathrm{M}$ methylmalonyl-CoA.

Additional file 4: Figure S3. Changes in coenzyme A, succinyl-CoA and methylmalonyl-CoA concentrations according to incubation time. The results are mean concentrations of CoA (Coenzyme A), SSCoA (succinyl$\mathrm{COA}$ ) and MMCoA (methylmalonyl-COA) for $66 \mu \mathrm{g}$ of protein incubated at $37^{\circ} \mathrm{C}$. The initial concentration of AdoCbl and MMCoA were $200 \mu \mathrm{M}$ and $263 \mu \mathrm{M}$ respectively. Tests were done twice at 5,10 and 40 minutes, five times at 0 minute and 8 times at 15, 20, 25 and 30 minutes. Inserted graph emphasizes the pattern of SSCOA.

Additional file 5: Table S2. Stability of three concentrations of standard solutions of methylmalonyl-CoA. The quality control (QC) study used three concentrations of the methylmalonyl-CoA measured in two assays during three consecutive days. The calculated accuracies varied from $84 \%$ to $93 \%$.

\section{Abbreviations}

RP-HPLC: Reversed-phase high performance liquid chromatography; CoA: Coenzyme A; MCM: Methylmalonyl-CoA mutase;

AdoCbl: Deoxyadenosylcobalamin; TCA: Trichloroacetic acid; CV: Coefficient of variation; S/N: Signal-to noise ratio; LOD: Limit of detection; LLOQ: Low limit of quantitation; SDS: Sodium dodecyl sulfate; SSCoA: Succinyl-CoA; MMCoA: Methylmalonyl-CoA; SA: Specific activity; Qc: Quality control.

\section{Competing interests}

The authors declare that they have no competing interests.

\section{Authors' contributions}

$\mathrm{CLG}$ participated to the design of the study and did a critical revision of the manuscript. BO designed the study, carried out the experiments, analysed the results and wrote the draft of the manuscript. MD provided biopsies of the lactating dairy cows and a critical revision of the manuscript. All authors read and approved the final manuscript.

\section{Acknowledgments}

This project and the fellowship to Bazoumana Ouattara were subsidized by an Agriculture and Agri-Food Canada grant and the Natural Sciences and 
Engineering Research Council of Canada (NSERC) Visiting Fellowships in Canadian Government Program. The authors would like to thank Veronique Roy for her technical assistance.

Received: 9 May 2013 Accepted: 8 October 2013

Published: 16 October 2013

\section{References}

1. Wolfle K, Michenfelder M, Konig A, Hull WE, Retey J: On the mechanism of action of methylmalonyl-CoA mutase. Change of the steric course on isotope substitution. Eur J Biochem 1986, 156:545-554

2. Evans PR, Mancia MF: Insights on the reaction mechanism of methylmalonyl-CoA mutase from the crystal structure. In Pages 217-226 in vitamin B12 and B12-proteins. Edited by Kräutler B, Arigoni D, Golding BT. Weinhem, Germany: Wiley-VCH; 1998.

3. Allen SH, Kellermeyer RW, Stjernholm RL, Wood HG: Purification and properties of enzymes involved in the propionic acid fermentation. J Bacteriol 1964, 87:171-187.

4. Gruber K, Kratky C: Methylmalonyl CoA mutase. Chichester: John Wiley \& Sons, Ltd; 2001.

5. Carrillo-Carrasco N, Venditti CP: Combined methylmalonic acidemia and homocystinuria, cblC type. II. Complications, pathophysiology, and outcomes. J Inherit Metab Dis 2012, 35:103-114.

6. Aschenbach JR, Kristensen NB, Donkin SS, Hammon HM, Penner GB: Gluconeogenesis in dairy cows: the secret of making sweet milk from sour dough. IUBMB Life 2010, 62:869-877.

7. Taoka S, Padmakumar R, Lai MT, Liu HW, Banerjee R: Inhibition of the human methylmalonyl-CoA mutase by various CoA-esters. J Biol Chem 1994, 269:31630-31634.

8. Graulet B, Matte JJ, Desrochers A, Doepel L, Palin MF, Girard CL: Effects of dietary supplements of folic acid and vitamin B12 on metabolism of dairy cows in early lactation. J Dairy Sci 2007, 90:3442-3455.

9. Reed $E B$, Tarver $\mathrm{H}$ : Urinary methylmalonate and hepatic methylmalonyl coenzyme A mutase activity in the vitamin B12-deficient rat. J Nutr 1970, 100:935-947.

10. Whitaker TR, Giorgio AJ: A direct radioassay of methylmalonyl-coenzyme A mutase using enzymatically synthesized DL-(3-14 C)methylmalonylCoA. Anal Biochem 1973, 52:522-532.

11. Scott JS, Treston AM, Bowman EP, Owens JA, Cooksley WG: The regulatory roles of liver and kidney in cobalamin (vitamin B12) metabolism in the rat: the uptake and intracellular binding of cobalamin and the activity of the cobalamin-dependent enzymes in response to varying cobalamin supply. Clin Sci (Lond) 1984, 67:299-306.

12. Morrow G 3rd, Barness LA, Cardinale GJ, Abeles RH, Flaks JG: Congenital methylmalonic acidemia: enzymatic evidence for two forms of the disease. Proc Natl Acad Sci U S A 1969, 63:191-197.

13. Kolhouse JF, Utley $\mathrm{C}$, Allen $\mathrm{RH}$ : Isolation and characterization of methylmalonyl-CoA mutase from human placenta. J Biol Chem 1980 255:2708-2712.

14. Kolhouse JF, Stabler SP, Allen RH: L-methylmalonyl-CoA mutase from human placenta. Meth Enzymol 1988, 166:407-414.

15. Cannata JJ, Focesi A Jr, Mazumder R, Warner RC, Ochoa S: Metabolism of propionic acid in animal tissues. Xii. Properties of mammalian methylmalonyl coenzyme a mutase. J Biol Chem 1965, 240:3249-3257.

16. Causey AG, Bartlett $K$ : A radio-HPLC assay for the measurement of methylmalonyl-CoA mutase. Clin Chim Acta 1984, 139:179-186.

17. Goodey PA, Gompertz D: Methylmalonyl CoA mutase--a radiochromatographic assay. Clin Chim Acta 1972, 42:119-123.

18. Kikuchi M, Hanamizu H, Narisawa K, Tada K: Assay of methylmalonyl CoA mutase with high-performance liquid chromatography. Clin Chim Acta 1989, 184:307-313.

19. Riedel B, Ueland PM, Svardal AM: Fully automated assay for cobalamin-dependent methylmalonyl CoA mutase. Clin Chem 1995, 41:1164-1170.

20. Wood HG, Kellermeyer RW, Stjernholm R, Allen SH: Metabolism of methylmalonyl-coa and the role of biotin and B12 coenzymes. Ann N Y Acad Sci 1964, 112:660-679.

21. Frenkel EP, Kitchens RL, Hersh LB, Frenkel R: Effect of vitamin B12 deprivation on the in vivo levels of coenzyme $A$ intermediates associated with propionate metabolism. J Biol Chem 1974, 249:6984-6991.
22. Watanabe F, Tarnura $Y$, Saido $H$, Nakano $Y$ : Enzymatic assay fur adenosylcobalamin-dependentm: ethy Imalonyl coenzyme A mutase. Biosci Biotechnol Biochem 1993, 57:1593-1594.

23. Peters JP, Elliot JM: Effects of cobalt or hydroxycobalamin supplementation on vitamin B-12 content and (S)-methylmalonyl-CoA mutase activity of tissue from cobalt-depleted sheep. J Nutr 1984, 114:660-670.

24. Xue GP, Snoswell AM, Runciman WB: Perturbation of methionine metabolism in sheep with nitrous-oxide-induced inactivation of cobalamin. Biochem Int 1986, 12:61-69.

25. Rice DA, McLoughlin M, Blanchflower WJ, McMurray CH, Goodall EA: Sequential changes in plasma methylmalonic acid and vitamin B12 in sheep eating cobalt-deficient grass. Biol Trace Elem Res 1989, 22:153-164.

26. Kennedy DG, Cannavan A, Molloy A, O'Harte F, Taylor SM, Kennedy S, Blanchflower WJ: Methylmalonyl-CoA mutase (EC 5.4.99.2) and methionine synthetase (EC 2.1.1.13) in the tissues of cobalt-vitamin B12 deficient sheep. Br J Nutr 1990, 64:721-732

27. Kennedy DG, Kennedy S, Blanchflower WJ, Scott JM, Weir DG, Molloy AM, Young PB: Cobalt-vitamin B12 deficiency causes accumulation of oddnumbered, branched-chain fatty acids in the tissues of sheep. Br J Nutr 1994, 71:67-76.

28. Kennedy DG, Young PB, Kennedy S, Scott JM, Molloy AM, Weir DG, Price J: Cobalt-vitamin B12 deficiency and the activity of methylmalonyl CoA mutase and methionine synthase in cattle. Int J Vitam Nutr Res 1995 65:241-247

29. Gaire D, Sponne I, Droesch S, Charlier A, Nicolas JP, Lambert D: Comparison of two methods for the measurement of rat liver methylmalonylcoenzyme A mutase activity: HPLC and radioisotopic assays. J Nutr Biochem 1999, 10:56-62.

30. Carlucci F, Rosi F, Tommassini $V$, Tabucchi A: CE assay of methylmalonylcoenzyme-a mutase activity. Electrophoresis 2007, 28:1921-1925.

31. Wen Y, Li J, Ma J, Chen L: Recent advances in enrichment techniques for trace analysis in capillary electrophoresis. Electrophoresis 2012, 33:2933-2952.

32. FDA USHaHS: Guidance for industry: bioanalytical method validation; 2001

33. Elliot JM: Propionate metabolism and vitamin B12. In Digestive physiology and metabolism in ruminants. Edited by Ruckebusch Y, Thivend P. Westport, Co. USA: AVI Publishing Co., Inc; 1979:485-503.

34. Lee Jl, Nguyen VT, Chen ML, Adamson PC: A rapid, sensitive and selective liquid chromatography/atmospheric pressure chemical ionization tandem mass spectrometry method for determination of fenretinide (4-HPR) in plasma. J Chromatogr B Analyt Technol Biomed Life Sci 2008, 862:64-71.

35. Lipsitz E, Moorthy G, Mosse Y, Fox E, Adamson PC: A sensitive and selective liquid chromatography/tandem mass spectrometry method for determination of MLN8237 in human plasma. J Chromatogr B Analyt Technol Biomed Life Sci 2010, 878:2369-2373.

36. Willard HF, Rosenberg LE: Interactions of methylmalonyl CoA mutase from normal human fibroblasts with adenosylcobalamin and methylmalonyl CoA: evidence for non-equivalent active sites. Arch Biochem Biophys 1980, 200:130-139.

37. Fenton WA, Hack AM, Willard HF, Gertler A, Rosenberg LE: Purification and properties of methylmalonyl coenzyme A mutase from human liver. Arch Biochem Biophys 1982, 214:815-823.

38. Wilkemeyer MF, Crane AM, Ledley FD: Primary structure and activity of mouse methylmalonyl-CoA mutase. Biochem J 1990, 271:449-455.

39. Gruber K, Puffer B, Krautler B: Vitamin B(12)-derivatives-enzyme cofactors and ligands of proteins and nucleic acids. Chem Soc Rev 2011, 40:4346-4363.

40. Reynolds CK, Huntington GB, Tyrrell HF, Reynolds PJ: Net portal-drained visceral and hepatic metabolism of glucose, L-lactate, and nitrogenous compounds in lactating holstein cows. J Dairy Sci 1988, 71:1803-1812.

41. Khan AM, SS S: Determination of critical micelle concentration $(\mathrm{Cmc})$ on sodium dodecyl sulfate (SDS) and the effect of low concentration of pyrene on its Cmc using ORIGIN software. J Chem Soc Pak 2008, 30:186-191.

42. Fabre $\mathrm{H}$, Altria KD: Validating CE methods for pharmaceutical analysis. In LC. Europe: GC; 2001:1-5.

doi:10.1186/1471-2091-14-25

Cite this article as: Ouattara et al:: Optimization and validation of a reversed-phase high performance liquid chromatography method for the measurement of bovine liver methylmalonyl-coenzyme a mutase activity. BMC Biochemistry 2013 14:25 